\title{
HUBUNGAN ANTARA KUALITAS AIR DENGAN PREVALENSI ENDOPARASIT PADA SALURAN PENCERNAAN IKAN NILA (Oreochromis niloticus) DI KERAMBA JARING APUNG PROGRAM URBAN FARMING DI KOTA SURABAYA
}

\section{The Effectifity of Extract of Garlic (Allium sativum) Against Aspergillus terreus IN VITRO}

\author{
Dandi Pradana ${ }^{1}$, Rahayu Kusdarwati ${ }^{2}$ dan Sudarno ${ }^{2}$. \\ ${ }^{1}$ Program Studi Budidaya Perairan, Fakultas Perikanan dan Kelautan, Universitas Airlangga, Surabaya \\ ${ }^{2}$ Departemen Manajemen Kesehatan Ikan dan Budidaya Perairan, Fakultas Perikanan dan Kelautan, Universitas \\ Airlangga, Surabaya \\ Email : fpk@unair.ac.id
}

\begin{abstract}
Abstrak
Aspergillus terreus adalah jamur yang menyebabkan penyakit aspergillosis. Ikan yang terinfeksi menunjukkan bercak putih abu-abu di atas tubuh. Perdarahan ulkus diamati pada insang dan kulit. Infeksi menyebabkan kematian ikan. Penggunaan bahan kimia untuk mengendalikan serangan jamur dapat membahayakan ikan, lingkungan dan manusia yang memakannya. Penggunaan tanaman obat merupakan cara yang aman untuk menghambat dan membunuh pertumbuhan jamur serta ramah lingkungan. Salah satunya yaitu menggunakan ekstrak bawang putih (Allium sativum).

Tujuan penelitian ini yaitu untuk mengetahui konsentrasi minimum ekstrak bawang putih sebagai antijamur terhadap pertumbuhan Aspergillus terreus in vitro. Percobaan dilakukan di Balai Karantina Juanda Kelas I Surabaya pada bulan Juni - Juli 2015. Metode yang digunakan dalam penelitian ini adalah metode difusi cakram kertas. Analisis yang digunakan dalam penelitian ini adalah statistik deskriptif.

Hasil penelitian dengan menggunakan ekstrak bawang putih konsentrasi 50\% sampai 90\% tidak menghasilkan zona bening di sekitar kertas, hal itu sama dengan kontrol negatif. Pada konsentrasi $100 \%$ tidak menunjukkan jamur tumbuh pada medium Sabouraud Dextrose Agar (SDA). Ini sama dengan kontrol positif. Kesimpulan dari penelitian ini bahwa daun kemangi tidak menunjukkan aktivitas antijamur dalam menghambat pertumbuhan jamur Aspergillus terreus.
\end{abstract}

Kata kunci: Aspergillus terreus, Aktivitas Antijamur, Bawang Putih (Allium sativum Linn) dan Zona Hambat

Abstract

Aspergillus terreus is a fungus that causes aspergillosis disease. The infected fishes showed grey white patches over the body. Haemorrhagic ulceratic patches were observed on the gill and skin. The infections resulted in the death of the fishes. The use of chemicals to control fungal attack can take the fishes into dangerous zone, the environment and humans who eat them. The use of medicinal plants is a safe way to inhibit and kill fungus growth as well as environmentally friendly. One of them uses extract of garlic (Allium sativum).

The purpose of this study was to determine the minimum concentration of activity and extract of garlic as antifungal against Aspergillus terreus growth in vitro. The experiment was conducted at the Balai Karantina Juanda Kelas I Surabaya in Juny - July 2015. The method used in this research that the paper disc diffusion method. The analysis used in this study is descriptive statistics.

The results of research using the extract of garlic concentration of $50 \%$ to $90 \%$ did not produce a clear zone around the paper, it is the same as the negative control. In the concentracion of $100 \%$ did not show fungus growing on Sabouraud Dextrose Agar medium (SDA). It is the same as the positive control. The conclusion of this study that basil leaves did not show antifungal activity in inhibiting the growth of fungus Aspergillus terreus.

Keywords: Aspergillus terreus, Antifungus Activity, Garlic (Allium sativum Linn) and Blocked Zone

\section{PENDAHULUAN}

Penyakit ikan merupakan salah satu masalah yang harus dihadapi dalam usaha budidaya perikanan. Salah satu penyakit yang menyerang ikan dalam usaha budidaya adalah aspergillosis yang 
disebabkan oleh jamur Aspergillus terreus. Saat ini infeksi Aspergillus terreus di Indonesia masih terdapat pada komposisi penyusun pakan ikan (Ahmad dkk., 1999). Adanya bercak putih abu-abu serta luka berdarah yang diamati pada insang dan kulit ditunjukkan pada ikan yang terinfeksi. Infeksi dapat mengakibatkan kematian ikan. Selain itu, Aspergillus terreus juga menghasilkan mikotoksin yang merupakan racun yang dikeluarkan oleh jamur dan bersifat mengganggu kesehatan. Adapun mikotoksin yang dihasilkan oleh Aspergillus terreus adalah citrinin dan terrein (Youssef et al., 2003) serta patulin (Hashem, 2011).

Untuk mengatasi permasalahan akibat serangan penyakit pada ikan, para petani maupun pengusaha ikan banyak menggunakan berbagai bahan-bahan kimia maupun antibiotika dalam pengendalian penyakit tersebut. Akan tetapi, antibiotik serta bahan kimia yang digunakan dengan konsentrasi/dosis yang tidak tepat secara terus menerus dapat menimbulkan masalah baru berupa meningkatnya resistensi mikroorganisme terhadap bahan tersebut. Selain itu, masalah lainnya adalah bahaya yang ditimbulkan terhadap lingkungan sekitarnya, ikan yang bersangkutan, dan manusia yang mengonsumsinya (Sugianti, 2005).

Metode yang paling tepat dalam penanggulangan hama dan penyakit yaitu metode yang tidak menimbulkan dampak terhadap lingkungan, baik jangka pendek maupun jangka panjang. Penggunaan bahan alami dalam penanggulangan hama dan penyakit khususnya jamur dinilai bersifat ramah lingkungan. Penggunaan bahan alami terus diteliti seperti penggunaan ekstrak bawang putih. (Kordi, 2004).

Ekstrak bawang putih ditemukan mempunyai antijamur. Thiosulfinate, terutama allicin merupakan komponen antijamur aktif mayor bawang putih. Komponen allicin dibentuk ketika sebutir bawang putih mentah dipotong dan dihancurkan. Pada saat itu enzim allinase dilepaskan dan mengkatalis pembentukan asam sulfenik dari cysteine sulfoxide. Asam sulfenik tersebut dapat saling bereaksi secara spontan serta membentuk senyawa yang tidak stabil yaitu thiosulfinate yang dikenal sebagai allicin. Bawang putih (Allium sativum) dengan kandungan senyawa sulfur, allicin dan sulfide dially trisulfide, sallylcysteine dan lainnya. Selain itu juga terdapat enzim allinase, peroxides, myrinase dan lain-lain (Kemper, 2000). Beberapa kandungan tersebut menjadikan bawang putih sebagai tanaman herbal yang sangat potensial sebagai obat alami yang bersifat anti jamur. Dari sisi ketersediaan dan kemudahan bahan, penggunaan bawang putih ini cukup berpeluang digunakan ditingkat pembudidaya ikan, mengingat tanaman ini mudah didapat.

\section{METODOLOGI}

\section{Waktu dan Tempat}

Penelitian telah dilaksanakan di Balai Karantina Juanda Kelas I Surabaya pada bulan Juli 2015.

\section{Materi Penelitian}

Peralatan Penelitian

Peralatan yang dibutuhkan dalam penelitian ini yaitu tabung reaksi, rak tabung reaksi, cawan petri, pembakar bunsen, ose, mikroskop, gelas objek, cover glass, autoclave, pipet ukur, pipet tetes, pengaduk, erlenmeyer, gelas ukur, timbangan digital, spektrofotometer, haemocytometer dan Rotary vacum evaporator.

\section{Bahan Penelitian}

Bahan yang dibutuhkan yaitu isolat murni Aspergillus terreus yang diperoleh dari stok Laboratorium Mikrobiologi Fakultas Sains dan Teknologi Universitas Airlangga Surabaya, bawang putih, air steril, aquades, etanol $96 \%$, Dimethyl sulfoxide (DMSO) 10\% dan Saboroud Dextrose Agar (SDA). 
Prosedur Kerja

Pembuatan Media Sabouraud Detroxe Agar

Media SDA adalah media untuk kultivasi jamur di cawan Petri. Tekstur media SDA kenyal dengan permukaan halus dan berwarna kuning pucat. Media SDA ini termasuk media padat (Pradhika, 2008). Bahan-bahan yang digunakan untuk membuat media SDA adalah serbuk Sabouraud Detroxe Agar dan akuades. Penggunaan media sangat penting untuk isolasi, diferensiasi maupun identifikasi. Untuk mendapatkan lingkungan hidup yang cocok bagi pertumbuhan jamur (Setiyani, 2010).

\section{Pembuatan Serbuk dan Ekstraksi Bawang Putih}

Bawang putih yang digunakan yaitu umbi bawang putih. Bawang putih dicuci dengan air mengalir, dipotong tipis kemudian dikeringkan dalam suhu kamar. Potongan bawang putih sebanyak 800 gram dimaserasi dengan menggunakan etanol $96 \%$ selama 3 x 24 jam dalam suhu kamar. Ekstrak bawang putih yang didapat dari proses dimaserasi sebanyak $10 \mathrm{ml}$. Menurut Ansel (1989) maserasi merupakan cara ekstraksi yang paling sederhana karena bahan yang akan diekstrak cukup dilarutkan di dalam pelarut. Selain itu pelarut yang digunakan dalam penelitian adalah etanol 96\%. Hal ini karena etanol dapat mengekstrak seluruh bahan aktif yang terkandung dalam bawang putih, terutama yang memiliki sifat antijamur. Larutan yang didapat kemudian disaring menggunakan kertas saring lalu diuapkan menggunakan Rotary vacum evaporator.

\section{Pembuatan Pelarut Ekstrak Bawang Putih}

Ekstrak bawang putih diencerkan dengan pelarut dimethylsulfoxide (DMSO). Pelarut DMSO yang digunakan yaitu kosentrasi $10 \%$, untuk membuat larutan tersebut maka diperlukan $10 \mathrm{ml}$ DMSO
$100 \%$ ditambahkan $90 \mathrm{ml}$ aquades (Assidqi, 2012).

\section{Identifikasi Jamur}

Inokulan yang akan digunakan pada penelitian, sebelumnya dilakukan identifikasi dengan melihat karakteristik morfologi dengan menggunakan mikroskop. Karakteristik Aspergillus terreus memiliki aksesoris konidia (aleuroconidia) yang tumbuh tunggal dari hifa dengan perbesaran 100x. (Deak et al., 2009).

\section{Pembuatan Suspensi Jamur}

Pembuatan suspensi jamur Aspergillus terreus dilakukan dengan mengambil spora dari biakan murni jamur Aspergillus terreus menggunakan ose. Jamur kemudian dipindahkan dalam tabung yang terisi akuades untuk mendapatkan suspensi jamur. Suspensi jamur diteteskan di haemocytometer kemudian ditempatkan pada mikroskop. Kepadatan konidia minimal yang akan digunakan adalah $10^{4}$ sel/ml (Alves et al., 2013).

\section{HASIL DAN PEMBAHASAN Hasil}

Proses identifikasi dilakukan untuk memastikan kebenaran terhadap isolat jamur yang didapatkan dari Balai Karantina Ikan Kelas I Surabaya I bahwa jamur tersebut adalah Aspergillus terreus. Identifikasi jamur dapat dilakukan dengan melihat secara mikroskopis dan makroskopis (Ilyas, 2007).

Pengamatan makroskopis pada sampel dilakukan dengan melihat karakteristik koloni yang tampak pada media SDA yang menunjukkan koloni jamur berwarna coklat. Balajee (2009) menyatakan bahwa warna koloni Aspergillus terreus beragam dari warna oranye muda sampai cokelat.

Pengamatan mikroskopis yang menunjukkan morfologi dari Aspergillus terreus yaitu konidiofor tidak berwarna (hialin), konidia berbentuk bulat, serta terdapat aleuroconidia. Hal ini sesuai 
dengan pendapat Balajee (2009) bahwa secara mikroskopis, Aspergillus terreus memiliki ciri konidiofor berbentuk panjang, berkolom, tidak berwarna (hialin) dan halus. Konidia memiliki bentuk bulat hingga bulat panjang dan striate serta

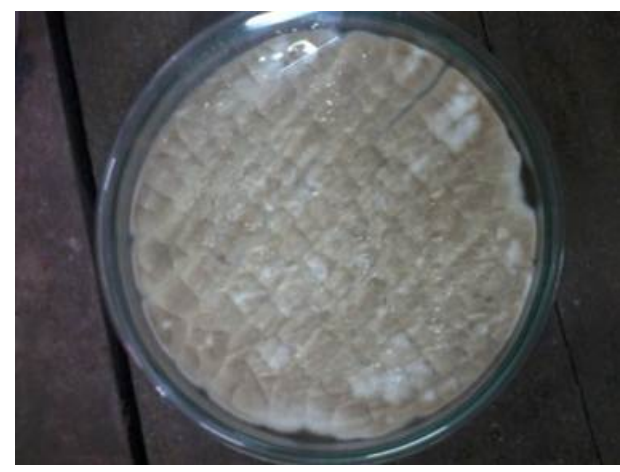

(a) dinding yang halus, sehingga dapat disimpulkan bahwa jamur tersebut adalah Aspergillus terreus Pengamatan secara makroskopis dan mikroskopis terlihat pada Gambar 1.

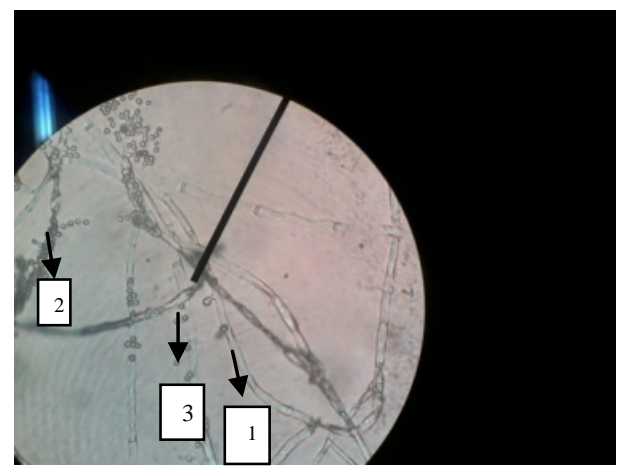

(b)

Gambar 1. Koloni Aspergillus terreus pada media Sabouraud Detroxe Agar (SDA) makroskopis (a). Aspergillus terreus pada mikroskop perbesaran 100x. Dengan keterangan (1. Hifa, 2. Konidia bulat, 3. Aleuroconidia) (b).

$\begin{array}{llll}\text { Hasil Uji Konsentrasi } & \text { Hambat } & & \text { antifungi dalam menghambat pertumbuhan } \\ \text { Minimum (KHM) } & & & \text { jamur. Hasil yang didapatkan pada } \\ \text { Pengamatan hasil uji potensi } & & \text { penelitian ini menunjukkan hasil yang } \\ \text { ekstrak bawang putih terhadap } & \text { positif karena terjadi zona hambat pada } \\ \text { pertumbuhan Aspergillus terreus } & \begin{array}{l}\text { konsentrasi yang diberikan dapat dilihat } \\ \text { dilakukan dengan melihat terjadinya zona }\end{array} & \text { pada Gambar } 2 .\end{array}$
hambat yang terjadi akibat mekanisme

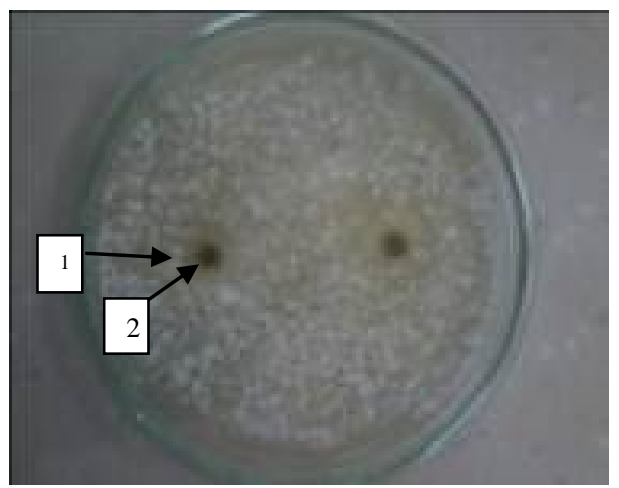

Gambar 2. Daya Hambat Bawang Putih Konsentrasi 100\%.

(1. Zona Hambat, 2. Kertas Cakram)

\begin{abstract}
Ekstrak bawang putih yang dihasilkan mampu menghambat pertumbuhan Aspergillus terreus. Hal itu ditunjukkan dengan terbentuknya zona hambat $1,1 \mathrm{~cm}$ pada konsentrasi $100 \%$ yang bersamaan dengan kontrol positif berupa larutan formalin 0,4\% yang mampu
\end{abstract}

menghambat Aspergillus terreus sebesar $1,3 \mathrm{~cm}$. Pengamatan dilakukan selama 48 jam dan diketahui hasilnya pada waktu jam ke 48 atau 2 hari. 
Hasil pengamatan Uji Konsentrasi Hambat Minimum

\begin{tabular}{|c|c|}
\hline $\begin{array}{c}\text { Konsentrasi } \\
(\%)\end{array}$ & $\begin{array}{c}\text { Diameter zona hambat } \\
(\mathrm{cm})\end{array}$ \\
\hline 10 & 0,0 \\
\hline 20 & 0,0 \\
\hline 30 & 0,0 \\
\hline 40 & 0,0 \\
\hline 50 & 0,0 \\
\hline 60 & 0,0 \\
\hline 70 & 0,0 \\
\hline 80 & 0,0 \\
\hline 90 & 0,0 \\
\hline 100 & 1,1 \\
\hline $\mathrm{K}(-)$ & 0,0 \\
\hline $\mathrm{K}(+)$ & 1,3 \\
\hline
\end{tabular}

\section{Pembahasan}

Hasil uji aktivitas antifungi ekstrak bawang putih (Allium sativum) terhadap jamur Aspergillus terreus telah dilakukan secara in vitro. Uji aktivitas antifungi dilakukan dengan uji Konsentrasi Hambat Minimum (KHM) dari konsentrasi 10\% hingga konsentrasi 100\%. Metode yang digunakan adalah metode difusi kertas cakram yang menunjukkan ekstrak bawang putih memiliki kemampuan dalam menghambat pertumbuhan jamur Aspergillus terreus. Hal ini dikarenakan terlihat terbentuknya zona hambat jamur di sekililing kertas cakram, hasil ini sesuai dengan kontrol positif sebagai pembanding yang juga terlihat adanya zona hambat di sekitar kertas cakram.

Tidak tumbuhnya koloni jamur pada kontrol positif yang berisi formalin membuktikan bahwa formalin mempunyai kemampuan dalam menghambat dan membunuh jamur. Formaldehyde (formalin) adalah bahan kimia yang sangat reaktif dan dapat berinteraksi dengan protein, DNA, serta RNA secara in vitro. Formalin dipilih karena menurut Hastuti (2010) bahwa formalin adalah senyawa antimikroba serbaguna yang salah satunya dapat membunuh jamur. Formaldehyde dianggap sporicidal berdasarkan kemampuannya untuk menembus ke bagian dalam spora jamur. Formaldehyde juga bereaksi secara ekstensif dengan asam nukleat (McDonnell and Denver Russell, 1999).

Sedangkan tumbuhnya koloni jamur pada kontrol negatif yang berisi 5 ml DMSO 10\% menunjukkan bahwa pelarut DMSO tidak mempengaruhi pertumbuhan jamur. Hal ini sesuai dengan Akoes et al., (2005) menyatakan bahwa DMSO tidak bersifat toksik dan karsinogenik pada konsentrasi 5\% - 10\% sehingga DMSO tidak ikut bereaksi dengan mikroba uji.

Ekstrak bawang putih dipilih karena mempunyai sifat antijamur. Kandungan bahan aktif pada bawang putih yang sudah diteliti yang dapat melawan jamur adalah minyak atsiri, flavonoid, dan allicin. Pada penelitian yang telah dilakukan dari ekstrak minyak atsiri bawang putih, menunjukkan aktivitas antifungi terhadap Fusarium solani, Penicillium funicolusum, Rhizomucor auricus dan Trichorderma reesi (Dharmagadda et al., 2005). Senyawa aktif yang dapat menghambat dan membunuh Aspergillus terreus didapatkan dari hasil ekstraksi dengan menggunakan etanol. Minyak atsiri pada ekstrak bawang putih sebagian besar banyak mengandung senyawa etil p- metoksisinamat (EPMS) yang umumnya dapat larut dalam pelarut etanol, etil asetat, methanol dan heksan (Barus, 2009).

Menurut Markham

flavonoid merupakan senyawa polar sehingga flavonoid dapat larut dalam pelarut polar seperti etanol, methanol, aseton, dimetil sulfoksida (DMSO) dan dimetil fonfamida (DMF). Menurut Waji dan Andis (2009) flavonoid merupakan senyawa metabolit sekunder yang terdapat pada tanaman. Flavonoid yang sering ditemukan pada tanaman yaitu flavon dan flavonol. Selain itu flavonoid mempunyai senyawa genestein berfungsi menghambat pembelahan atau proliferasi sel jamur. Senyawa ini mengikat protein pada mikrotubulus dalam sel dan mengganggu 
fungsi mitosis sehingga menimbulkan penghambatan pertumbuhan jamur. Pengaruh senyawa fenol sebagai antifungal adalah dengan mendenaturasi ikatan protein pada membran sel sehingga membran sel lisis dan memungkinkan fenol menembus ke dalam inti sel yang menyebabkan jamur tidak bekembang (Sulistyawati dan Mulyati, 2009).

\section{KESIMPULAN DAN SARAN Kesimpulan}

Dari penelitian ini dapat disimpulkan bahwa kstrak bawang putih (Allium sativum) dapat menghambat pertumbuhan Aspergillus terreus secara in vitro sehingga terdapat aktivitas antijamur terhadap Aspergillus terreus. Ekstrak bawang putih (Allium sativum) konsentrasi $100 \%$ (5 ml ekstrak bawang putih) mampu menghambat pertumbuhan Aspergillus terreus dan pada kontrol positif berupa larutan formalin mampu menghambat pertumbuhan Aspergillus terreus.

\section{Saran}

Penggunaan ekstrak bawang putih sebagai antifungi perlu dipertimbangkan lagi. Penelitian menggunakan ekstrak bawang putih sebagai antifungi sebaiknya menggunakan metode lainnya agar mendapatkan hasil yang optimal dalam menghambat Aspergillus terreus.

\section{DAFTAR PUSTAKA}

Ahmad, R.Z., D. Gholib, Subiyanto, dan S.Hastiono. 1996. Tinjauan retrospektif kapang toksigenik pada berbagai sampel pakan dan komponennya. Prosiding Pertemuan Ilmiah Nasional Bidang Veteriner, Bogor. Balai Penelitian Veteriner, Bogor. 339 hal.

Alves, J. L., J. H. C. Woudenberg, L. L. Duarte, P. W. Crous, and R. W. Barreto. 2013. Reappraisal of The Genus Alternariaster (Dothideomycetes). The Netherlands. Persoonia. pp. 77-85.
Balajee, S.A. 2009. Aspergillus terreus complex. Medical Mycology, 47 (Supplement 1). pp. 42-46.

Deak E, Wilson SD, White E, and Carr JH, Balajee SA. 2009. Aspergillus terreus accessory conidia are unique in surface architecture, cell wall composition and germination kinetics. Plos One, 4:7673.

Dharmagadda, V. S. S., M. Tandonb, and P. Vasudevan. 2005. Biocidal activity of the essential oils of Lantana camara, Ocimum sanctum and Tagetes patula. Journal of Scientific \& Industrial Research. 64 : 53-56.

Hashem, M. 2011. Isolation of Mycotoxinproducing Fungi from Fishes Growing in Aquacultures. Research Journal of Microbiology. ISSN 1816-4935 : 6-8.

Kathi J. Kemper. 2000. Garlic (Allium sativum).

http://www.mcp.edu/herbal/default. htm. Diunduh 17 April 2014

Kordi, K.M.G. 2004. Penanggulangan Hama dan Penyakit Ikan. Cetakan Pertama. Jakarta: Rineka Cipta.

McDonnell, G and A. Denver Russell. 1999. Antiseptics and Disinfectants: Activity, Action, and Resistance. Clinical Microbiology Reviews. pp. 153.

Pradhika, I. 2008. Mikrobiologi Dasar. http://www.shoutmix.com. 10 Mei 2013. hal 7.

Youssef, M. S., N. F. Abo-Dahab and R. M. Farghaly. 2003. Studies on Mycological Status of Salted Fish "Moloha" in Upper Egypt. Mycobiology. 31 (3) : 166 - 172. 